\title{
LOCUS OF CONTROL, MOTIVASI BERPRESTASI DAN SIFAT JIWA WIRAUSAHA PADA MAHASISWA ITS
}

\begin{abstract}
Sri Mulyono
Abstrak

Karya McClelland tentang motif berprestasi (N-Ach) sebagai suatu sifat wirausaha pokok telah mendorong berbagai bidang penelitian kewirausahaan. Selain motivasi berprestasi, karakteristik psikologis lain dari wirausahawan adalah Internal Locus of Control.Locus of Control adalah ciri pribadi yang sifatnya " tergantung pada kekuatan dari dalam diri, dan karenanya bersifat menentukan nasib diri sendiri, berkeinginan kuat untuk independen dan otonom ".Tujuan penelitian ini untuk menguji dua sifat tersebut yaitu dengan mencari hubungan antara motivasi berprestasi dengan Locus of Control sebagai jiwa wirausaha. Selain itu ingin diketahui bagaimana profil awal pribadi sifat jiwa wirausaha yang dimiliki oleh mahasiswa ITS. Hasil penelitian menunjukkan angka korelasi ( $r$ ) angka .3741 dan dinyatakan signifikan dalam taraf signifikansi .01.Dengan demikian hipotesis yang menyatakan ada hubungan yang positif antara Locus of Control dan Motivasi Berprestasi dari mahasiswa ITS adalah diterima. Sedangkan profil keberadaan sifat jiwa wirausaha pada mahasiswa ITS adalah tergolong masih rendah dan cukup yaitu $39,2 \%$ mempunyai sifat jiwa wirausaha yang rendah dan $57,2 \%$ mempunyai sifat kewirausahaan yang cukup saja, dan hanya ada $3,6 \%$ saja yang tergolong mempunyai sifat jiwa kewirausahaan yang tergolong tinggi dan belum ada yang tergolong mempunyai sifat kewirausahaan yang sangat tinggi.Dari penelitian ini dapat diambil kesimpulan bahwa memang ada hubungan antara Locus of Control dengan motivasi berprestasi pada mahasiswa ITS, dan sifat jiwa kewirausahaan mahasiswa ITS masih tergolong kurang dan hanya cukup saja, maka dalam rangka menumbuhkan mentalitas kewirausahaan untuk menciptakan kerja sendiri maka perlu diciptakan iklim yang lebih mendukung untuk tercapainya tujuan perkuliahan kewirausahaan di ITS.
\end{abstract}

Kata Kunci: Locus of Control, Motivasi berprestasi, sifat jiwa wirausaha.

Dimulai pada semester gasal tahun ajaran 1999/2000 ITS telah melaksanakan perkuliahan kewirausahaan bagi semua mahasiswa di lingkungan ITS. Kuliah kewirausahaan ini dibawah koordinasi Jurusan MKU-F.MIPA dan Lembaga Pengabdian Masyarakat ITS. Tujuan dilaksanakannya mata kuliah kewirausahaan ini adalah untuk menyiapkan mahasiswa agar dapat bekerja secara mandiri dan menciptakan lapangan kerja sendiri sehingga dapat mengatasi permasalahan lapangan pekerjaan di negara kita.

Kegiatan belajar-mengajar ini selain dilaksanakan oleh dosen dengan pendekatan ilmu pengetahuan juga dilaksanakan dengan mengundang praktisi wirausaha untuk memberikan pengalamannya dan berdiskusi berdasarkan faktafakta di lapangan. Maka untuk mendasari perkuliahan dengan ilmu pengetahuan 
yang obyektifitasnya dapat diuji maka perlu dilakukan penelitian-penelitian dalam bidang yang relevan untuk pengembangan ilmu tersebut.

Mata kuliah kewirausahaan merupakan mata kuliah yang membahas suatu masalah yang bersifat multi-dimensional. Sebab hakekat wirausaha dan kewiraswastaan adalah merupakan suatu kesatuan masalah yang meliputi banyak segi, seperti ciri-ciri umum wiraswasta, jenis usaha, manajemen, permodalan, dan sebagainya. ( Umar Nimran,1990, dalam makalah yang disampaikannya pada ILO-ITS Training Course On Self Employment And Entrepeneurship Development).

Penelitian awal tentang kewirausahaan secara spesifik memfokuskan diri pada sifat pribadi atau latar belakang individu dari wirausaha sebagai determinan perilaku wirausahaan ( Low \& McMillan, 1998). Perlu dicatat bahwa karya McClelland tentang Motif berprestasi ( N-Ach ) sebagai suatu sifat wirausaha pokok telah mendorong berbagai bidang penelitian kewirausahaan ( Umar Nimran,1990 ).

Selain motivasi berprestasi, penelitian lain seperti Shapero, mengemukakan karakteristik psikologis lain dari wirausahawan adalah Internal Locus of Control. Locus of Control adalah ciri pribadi yang sifatnya " tergantung pada kekuatan dari dalam diri, dan karenanya bersifat menentukan nasib sendiri, berkeinginan kuat untuk independen dan otonom “.

Berdasarkan dua karakteristik penting sifat jiwa wirausaha diatas penulis berminat untuk menguji dua sifat tersebut yaitu dengan mencari hubungan antara motivasi berprestasi dengan Locus of Control sebagai jiwa wirausaha karena sepengetahuan penulis belum ada peneliti yang secara spesifik telah melakukan pengujian dalam hal ini.

Penelitian ini akan sangat bermanfaat untuk mendapatkan jawaban ilmiah dalam ilmu psikologi khususnya dan bermanfaat dalam pengembangan pengetahuan kewirausahaan untuk memperkaya hasil penelitiaanya yang dapat dikembangkan untuk analisis dalam perkuliahan kewirausahaan yang baru dirintis, dan mengetahui sifat jiwa wirausaha mahasiswa ITS. 
Secara spesifik tujuan penelitian yang akan dicapai adalah mengadakan pengukuran Locus of Control dan Motivasi Berprestasi dari mahasiswa ITS yang dianggap sebagai faktor penting yang menentukan dalam sifat kewirausahaan dan mengadakan pengujian apakah ada hubungan diantaranya. Secara umum ingin diketahui bagaimana profil awal pribadi sifat jiwa wirausaha yang dimiliki oleh mahasiswa ITS dan akan dibina sebagai salah satu tujuan kuliah kewirauhaan di ITS.

Masalah kewirauhaan dan wirausaha menjadi topik penting dan banyak dibicarakan pada akhir-akhir ini. Bahkan oleh sementara pihak hal ini dipandang sebagai salah satu alternatif yang paling menjanjikan untuk memecahkan masalah dibidang lapangan kerja yang kian hari kian sulit. Sebagai konsekuensinya pemikiran-pemikiran dan usaha-usaha yang mendorong terciptanya dan majunya wirausaha dan kewirauhaan terus dilakukan oleh berbagai pihak, termasuk pemerintah dan perguruan tinggi (Umar Nimran,1990). Kata wiraswasta atau kewiraswastaan masih relatif baru dalam khasanah / perbendaharaan bahasa Indonesia. Kedua kata itu dipakai sebagai terjemahan kata "enterpreneur" dan "entrepreneurship". Enterpreneur mengandung pengertian orang yang berusaha atau bekerja sendiri/mandiri atau "self-employed person" sedangkan kewiraswastaan adalah hal ikhwal yang berkenaan dengan usaha sendiri/mandiri itu. Di dalam literatur indonesia, ternyata kata wiraswasta dan kewiraswastaan oleh beberapa penulis juga dipakai secara silih berganti dengan wirausaha dan kewirausahaan. (Soemardjan,1979, Rusli,1988).

Seperti telah dikemukakan, bahwa penelitian awal tentang kewirauhaan memfokuskan diri pada pribadi atau latar belakang individu dari wirausahawan sebagai determinan perilaku wirausahanya (Low \& Mc Millan, 1988). Selanjutnya dalam perjalanan waktu, pendekatan ini melahirkan pemikiran akan perlunya penelitian yang bersifat konstektual dan memfokuskan diri pada orientasi proses. Mengenai hal ini karya McClelland $(1965,1967)$ tentang "motif berprestasi" (Need of Achivement/ N-Ach) telah mendorong penelitian-penelitian dibidang kewirausahaan. Dikatakan oleh McClelland bahwa motif berprestasi adalah sesuatu yang diperoleh secara kultural dan merupakan ciri kunci dari seorang 
wirausahawan. McClelland mengartikan motivasi berprestasi sebagai virus kepribadian yang menyebabkan seseorang ingin selalu berbuat lebih baik dan ingin terus maju, selalu berpikir untuk berbuat yang lebih baik dan memiliki tujuan yang realistik. Seseorang yang memiliki N-Ach tinggi biasanya lebih menyukai situasi-situasi kerja yang dapat mereka ketahui apakah akan mengalami peningkatan/kemajuan atau tidak, uang bagi mereka bukanlah tujuan.

Sedangkan Edwards menunjukkan ciri-ciri motif berprestasi yang tinggi adalah sebagai berikut (Yuniarti,1988):

1. Melakukan sesuatu dengan sebaik-baiknya

2. Melakukan sesuatu dengan sukses

3. Mengerjakan sesuatu dan menyelesaikan tugas-tugas yang memerlukan usaha dan ketrampilan

4. Ingin menjadi pengusaha yang terkenal dan terpandang dalam suatu bidang tertentu

5. Mengerjakan sesuatu yang sangat berarti atau penting

6. Melakukan suatu pekerjaan yang sukar dengan baik

7. Menyelesaikan teka-teki dan sesuatu yang sukar

8. Melakukan sesuautu yang lebih baik dari orang lain

Jadi dengan mengkaji ketiga ciri-ciri orang yang bermotif prestasi $(\mathrm{N}$ Ach) tinggi kiranya beralasan jika hal tersebut dikatakan sebagai salah satu ciri pribadi (personal) wirausaha yang penting dan utama.

Peneliti lain yaitu Shapero yang dikutip oleh Hutchinson (1983) mengemukakan bahwa karakteristik psikologis lain wirausahawan yang disebutkan dalam literatur adalah "Internal Locus of Control" (letak kendali internal). Internal Locus of Control adalah ciri pribadi yang sifatnya "adalah tergantung pada pada kekuatan dari dalam diri, dan karenanya bersifat menentukan nasib sendiri, berkeinginan kuat untuk independen dan otonom".

Levenson membagi Locus of Control dalam tiga faktor yaitu :

1. Faktor Internal (I) adalah keyakinan seseorang bahwa kejadian-kejadian dalam hidupnya ditentukan terutama oleh kemampuan dirinya sendiri. 
2. Faktor Powerful Others (P) adalah keyakinan seseorang bahwa kejadiankejadian dalam hidupnya ditentukan terutama oleh orang lain yang lebih berkuasa

3. Faktor Chance (C) adalah keyakinan seseorang bahwa kejadian-kejadian dalam hidupnya ditentukan terutama oleh nasib,peluang, dan keberuntungan.

Faktor 1 atau (I) adalah Internal Locus of Control, sedangkan faktor 2 (P) dan faktor 3 (C) adalah eksternal Locus of Control.

Dari uraian yang diberikan oleh ahli diatas dapat diambil pengertian bahwa motivasi berprestasi adalah kebutuhan untuk mencapai yang lebih baik atau berusaha terus menerus melakukan sesuatu dengan lebih baik.

Sedangkan Internal Locus of Control (Robbins,1986) adalah taraf dimana seseorang percaya bahwa dirinyalah yang menentukan nasibnya sendiri. Pada orang yang tinggi taraf kendali internalnya, maka segala keputusan, tindakan dan resiko atas tindakannya dan sebagainya hampir sepenuhnya dia sendiri yang menentukan, bukan oleh orang lain, ataupun oleh nasib.

Dalam hubungan antara Locus of Control dengan motivasi berprestasi dapat dijelaskan ; bahwa seseorang yang mempunyai taraf Locus of Control Internal yang tinggi maka ia akan mempunyai sifat tidak percaya bahwa nasibnya telah ditentukan, ia percaya bahwa nasibnya adalah dia sendiri yang menentukan, ia percaya bahwa apa yang diperbuatnya akan menimbulkan resiko pada dirinya sendiri dan ia merasa bertanggung jawab dan tidak mempersalahkan orang lain, dan ia percaya bahwa sepenuh keberhasilannya adalah dia sendiri yang menentukan; bukan ditentukan orang lain. Dengan adanya sifat Locus of Control Internal seperti itu akan mudah dipahami bahwa Locus of Control Internal dan menimbulkan motivasi berprestasi. Dengan kata lain yang singkat, bahwa seseorang yang mempunyai keyakinan bahwa keberhasilan adalah dari dalam dirinya sendiri dan bukan dari orang lain ataupun nasib maka akan menimbulkan dorongan untuk berbuat sebaik-baiknya dan selalu ingin lebih maju demi pencapaian prestasi pribadi (personal achievement)

Dari beberapa temuan hasil penelitian yang berusaha mengidentifikasi ciri-ciri wirausaha, dilaporkan ternyata cukup banyak ciri penting yang dimiliki 
oleh wirausahawan. Tetapi masih diakui bahwa untuk mengidentifikasi seluruh ciri atau sifat wirausahawan masih merupakan pekerjaan yang sulit karena belum ada definisi yang tuntas karena banyaknya faktor yang terlibat. Umar Nimran (1990) menyebutkan ciri-ciri atau kualitas pribadi wirausahawan yang penting diantaranya adalah sebagai berikut: motif berprestasi yang tinggi, internal locus of control, independen, otonom, kepercayaan diri yang tinggi, inovasi dan kreativitas yang tinggi, tanggung jawab yang besar, berinisiatif, cerdik, memiliki kepemimpinan, energi yang tinggi, tekun dan kerja keras, keuletan.

Payaman Simanjuntak (1988) menyebutkan secara garis besar sebagai berikut : Percaya diri sendiri, berorientasi pada pencapaian sassarn, bersedia mengambil resiko, berpandangan jauh kedepan. Sedangkan aspek jiwa wirausaha yang tertulis di draft buku kewirausahawan ITS (1999) adalah sebagai berikut: Lebih suka resiko yang moderat, menyenangi pekerjaan yang berkaitan dengan proses mental dengan tujuan utama adalah pencapaian prestasi pribadi, locus of control internal, kemampuan inovasi dan kreatifitas, cenderung untuk berpikir panjang,memiliki potensi untuk melakukan visi yang jauh kedepan dan kemandirian.

Dari hasil penelitian Sri Mulyono mengenai Profile Minat Mahasiswa Perguruan Tinggi Teknik Terhadap Pekerjaan (Sri Mulyono,1990) ternyata ditemukan hasil yang menggembirakan bahwa dari 50 jenis pekerjaan yang disajikan ternyata pekerjaan wirausaha yaitu sebagai pemilik usaha perdagangan besar/eceran menempati pilihan urutan no.2, yaitu $60 \%$ dari responden, hanya dibawah urutan no.1 yaitu sebagai ahli teknik (70\%). Pilihan pekerjaan sebagai wirausahawan ini paling tidak memberikan gambaran kemungkinan tingginya sifat jiwa wirausaha pada mahasiswa perguruan tinggi teknik.

\section{METODE PENELITIAN}

1. Variabel-variabel dalam penelitian ini adalah :
a. Motivasi berprestasi sebagai variabel tergantung
b. Locus of control sebagai variabel bebas
c. Sifat jiwa wirausaha, yang dianalisa secara deskriptif

2. Definisi operasional variabel penelitian 
Motivasi berprestasi adalah keinginan untuk berbuat sebaik-baiknya atau lebih baik dan ingin terus maju yang ditunjukkan dengan :

a. Melakukan sesuatu dengan sebaik-baiknya

b. Melakukan sesuatu dengan sukses

c. Mengerjakan sesuatu dan menyelesaikan tugas-tugas yang memerlukan usaha dan ketrampilan

d. Ingin menjadi pengusaha yang terkenal dan terpandang dalam suatu bidang tertentu

e. Mengerjakan sesuatu yang sangat berarti atau penting

f. Melakukan suatu pekerjaan yang sukar dengan baik

g. Menyelesaikan teka-teki dan sesuatu yang sukar

h. Melakukan sesuautu yang lebih baik dari orang lain

Locus of Control adalah ciri pribadi yang sifatnya "adalah tergantung pada kekuatan dari dalam diri, dan karenanya bersifat menentukan nasib sendiri, berkeinginan kuat untuk independen dan otonom"

Variabel locus of control dibagi dalam tiga faktor yaitu:

a. Faktor Internal (I) adalah keyakinan seseorang bahwa kejadian-kejadian dalam hidupnya ditentukan terutama oleh kemampuan dirinya sendiri.

b. Faktor Powerful Others (P) adalah keyakinan seseorang bahwa kejadiankejadian dalam hidupnya ditentukan terutama oleh orang lain yang lebih berkuasa

c. Faktor Chance (C) adalah keyakinan seseorang bahwa kejadian-kejadian dalam hidupnya ditentukan terutama oleh nasib,peluang, dan keberuntungan

Faktor a atau (I) adalah Internal Locus of Control, sedangkan faktor b (P) dan faktor c (C) adalah eksternal locus of control.

Sifat jiwa wirausaha adalah ciri-ciri psikologis kepribadian yang meliputi : Pengambilan resiko yang yang moderat, pengejaran prestasi pribadi, keyakinan seseorang bahwa kejadian-kejadian dalam hidupnya ditentukan terutama oleh kemampuan dirinya sendiri, kemampuan menemukan cara baru yang kreatif , kemampuan mengolah potensi jangka panjang dan kemandirian.

3. Alat pengumpulan Data 
Alat pengumpulan data dari variabel-variabel yang telah ditentukan digunakan angket. Untuk mngempulkan data motivasi berprestasi dari Edwards. Untuk mengumpulkan data locus of control digunakan skala IPC Locus of Control dari Levenson, dan untuk mengempulkan data sifat jiwa wirausaha digunakan angket sifat jiwa wirausaha. Data-data dikumpulkan dari hasil pengukuran ini merupakan data interval.

4. Populasi dan Sampel

Populasi dalam penelitian ini adalah semua mahasiswa ITS yang sedang mengikuti kuliah pada semester genap tahun ajaran 1999/2000. Sample dalam penelitian diambil secara random dari beberapa jurusan yang ada di ITS.

5. Analisa Data

Data dari hasil pengukuran variabel yang hendak di uji adalah dari hasil pengukuran variabel motivasi berprestasi dan variabel locus of control yang berupa data kwntitatif interval maka pola analisa menggunakan analisa statistik.

Sesuai hipotesis yang diajukan yaitu : "ada hubungan yang positif antara locus of control dan motivasi berprestasi dari mahasiswa ITS", maka teknik statistik yang digunakan untuk mencari saling hubungan dalah teknik statistik korelasional untuk data interval baik untuk variabel bebas maupun variabel tergantung adalah teknik statistik product moment dari pearson.

Perhitungan statistik menggunakan jasa progam komputer yaitu SPSS for WINDOWS Release 6.0, Copyright CSPSS Inc, 1989-1993, All Right reserved. Keputusan hasil uji hipotesis digunakan tarif signifikansi $1 \%$ dan $5 \%$.

Untuk mengetahui bagaimana profil sifat jiwa wirausaha mahasiswa ITS dilakukan analisa diskriptif, yaitu ingin diketahui besarnya sifat jiwa wirausaha dan distribusi frekuensinya.

\section{HASIL PENELITIAN}

Populasi penelitian ini adalah mahasiswa ITS Surabaya, penelitian dilaksanakan pada sampel yang diambil secara random. Sampel yang diambil dari mahasiswa berbagai jurusan di ITS itu terkumpul sejumlah 360 orang mahasiswa. 
Mereka diminta menjawab angket yang sudah dirancang untuk mengukur variabel-variabel yang hendak diteliti yaitu:

1. Angket untuk mengukur variabel locus of control. Terdiri dari 20 item yang mengungkap faktor-faktor locus of control, responden harus menjawab Benar atau Salah pada setiap item. Skor untuk variabel locus of control untuk setiap responden adalah berkisar dari nilai terendah yaitu 0 dan tertinggi 100 .

2. Angket untuk mngukur variabel motif berprestasi. Terdiri dari 38 item yang mengungkap motivasi berprestasi dari responden. Responden diminta menjawab dengan pilihan Sangat tidak Setuju, tidak setuju, Tidak dapat Menentukan, Setuju, dan Sangat Setuju untuk setiap pertanyaan yang diajukan. Jumlah skor untuk setiap responden pada variabel motivasi berprestasi ini adalah bergerak dari yang terendah yaitu 0 dan yang tertinggi adalah 152.

3. Angket untuk mengukur sifat jiwa wirausaha terdiri dari 50 item responden harus memberi jawaban pada setiap pertanyaan dengan pernyataan sangat tidak setuju, tidak setuju, tidak dapat menentukan, setuju dan sangat setuju. Untuk setiap pertanyaan diberi skor, sedangkan skor keseluruhan yang menggambarkan sifat jiwa wirausaha untuk setiap responden adalah berkisar dari yang terendah 0 hingga yang tertinggi 200.

Setelah diadakan skoringdan tabulasi skor yang berbentuk data kwantitatif, maka untuk menguji hipotesis yang diajukan ; bahwa ada hubungan yang positif antara locus of control dan motivasi berprestasi mahasiswa ITS, data diolah dengan teknik statistik product moment dari pearson. Perhitungan statistik menggunakan jasa progam komputer yaitu SPSS for WINDOWS Release 6.0, Copyright @SPSS Inc, 1989-1993, All Right reserved dengan hasil (output) dari SPSS sebagai berikut:

$\begin{array}{cc}\text { Locus Control } & \text { Motivasi Prestasi } \\ 1.0000 & .3741^{* *} \\ .3741^{* *} & 1.0000 \\ & * * \text { Signif LE .01 }\end{array}$


Dari output SPSS tersebut nampak bahwa korelasi ${ }^{\circledR}$ menunjukkan angka .3741 dan dinyatakan signifikan dalam taraf signifikasi .01.

Dengan demikian hipotesis yang menyatakan ada hubungan yang positif antara Locus of Control dan motivasi berprestasi dari mahasiswa ITS adalah diterima.

Untuk melihat bagaimana profil sifat jiwa wirausaha mahasiswa ITS dapt diketahui dari sebaran skor atau distribusi frekuensi skor angket yang mengungkap sifat jiwa wirausaha yang diberikan kepada sample sebagai responden.

Distribusi frekuensi skor angket sifat jiwa wirausaha adalah sebagai berikut :

\begin{tabular}{lll} 
Value & Frekuensi & Percent \\
\hline 93 & 12 & 3.3 \\
95 & 6 & 1.7 \\
98 & 1 & 0.3 \\
100 & 12 & 3.3 \\
102 & 24 & 6.7 \\
103 & 12 & 3.3 \\
104 & 11 & 3.1 \\
105 & 12 & 3.3 \\
106 & 11 & 3.1 \\
108 & 12 & 3.3 \\
109 & 11 & 3.1 \\
110 & 17 & 4.7 \\
114 & 33 & 9.2 \\
115 & 36 & 10 \\
116 & 12 & 3.3 \\
117 & 9 & 2.5 \\
118 & 6 & 1.7 \\
119 & 12 & 3.3 \\
121 & 12 & 3.3 \\
123 & 13 & 3.6
\end{tabular}




$\begin{array}{lll}125 & 18 & 5 \\ 126 & 9 & 2.5 \\ 129 & 12 & 3.3 \\ 131 & 12 & 3.3 \\ 137 & 13 & 3.6 \\ 144 & 9 & 2.5 \\ 156 & 13 & 3.6 \\ & -------- \\ \text { Total } & 360 & 100\end{array}$

Berdasarkan kriteria bahwa ; skor

$0 \quad$-- -- 60 : sangat kurang

61 ---- 110 : rendah

111 ----- 150 :cukup

151 ---- 180 : tinggi

181 ---- 200 : sangat tinggi

Dari distribusi frekuensi sifat jiwa wirausaha dapat digambarkan bahwa profil keberadaan sifat jiwa wirausaha pada mahasiswa ITS adalah masih rendah dan cukup, yaitu 39,2\% mempunyai sifat jiwa wirausaha yang rendah dan 57,2\% mempunyai sifat kewirausahaan yang cukup saja, dan hanya ada 3,6\% saja yang tergolong mempunyai sifat jiwa kewirausahaan yang tergolong tinggi dan belum ada yang tergolong mempunyai sifat kewirausahaan yang sangat tinggi.

\section{KESIMPULAN}

Dari penelitian ini dapat diambil kesimpilan bahwa memang ada hubungan antara Locus of Control dengan motivasi berprestasi pada mahasiswa ITS, artinya pada mahasiswa ITS apabila mempunyai Locus of Control eksternal yang tinggi maka mereka juga akn mempunyai motivasi berprestasi yang tinggi pula, dan sebaliknya.

Bahwa sifat jiwa kewirausahaan mahasiswa ITS masih tergolong kurang dan hanya cukup saja, maka dalam rangka menumbuhkan mentalitas kewirausahaan untuk menciptakan kerja sendiri maka perlu diciptakan iklim yang lebih mendukung untuk tercapainya tujuan perkuliahan kewirausahaan di ITS.

\section{DAFTAR PUSTAKA}


Burch J.G, (1988) Entrepreneurship. John Wiley and Sons. New York Hutchinson, P.J. (1983). The Role of Entrepreneur in Small Enterprise Development. Management Forum, 9. 5-13.

McClelland, D.(1965). Need Achievement and Entrepreneurship. Journal of Personality and Social Psychology, 1, 389-392.

Meredith G.G.,Nelson R.E., and Neck P.A. (1983). The Process of Entrepreneurship, ILO, Geneva.

Mulyono, Sri. (1990). “ Profile Minat Mahasiswa Perguruan Tinggi Teknik Terhadap Pekerjaan ” Laporan Penelitian, Lemlit ITS

Nimran, Umar. (1990). Personal Qualities of Entrepreneurs. Makalah ILO-ITS Training Course On Self Employment and Entrepreneurship Development. Surabaya

Robbin, S.P. (1986). Organizational Behavior, Englewood Cliff, Prentice Hall Intenational. New York.

Simanjutak, Pajaman J. (1988). Kerja Mandiri dan Kewirausahaan. Surabaya. Departemen Tenaga Kerja RI.

Soemardjan, S. (1979). Timbulnya Kewiraswastaan dalam masyarakat Indonesia. Malang. FKK Univ Brawijaya.

Yuniarti. (1988). Pola Asuh Anak, Self-Esteem, Motivasi Berprestasi, dan Prestasi Belajar. Skripsi. Yogyakarta : Universitas Gadjah Mada. 